\title{
Women and Hoax News Processing on WhatsApp
}

\author{
Hani Noor Ilahi \\ University of Indonesia \\ (email: hani.kpppa@gmail.com)
}

\begin{abstract}
The word hoax became popular with the development of technology that has potentially increased the circulation of hoax news. One of the ways hoax news circulates is through mobile instant messaging applications like WhatsApp, where users can interact directly, or between individuals who are members of a group. In Indonesia, by 2017, WhatsApp was the most used and the longestused mobile instant messaging application, having 35.87 million users. This study focuses on women using WhatsApp, as previous studies have shown that women dominate social media use in Indonesia. Using the elaboration likelihood model, this study aimed to investigate how women process hoax messages about child abduction on WhatsApp. The results of research through interviews and surveys indicate that women tend to process hoax messages about the abduction of children through peripheral lines. The lack of media literacy and the tendency to prioritize the emotional aspects of a story make some women vulnerable to spreading hoaxes through WhatsApp. In this study, the researchers recommend a digital empowerment movement to improve women's media literacy through an online lecture model on WhatsApp. This program should be professionally managed by experts or academics from relevant fields of study.
\end{abstract}

\section{Keywords:}

hoax news; abduction; mobile instant messaging; WhatsApp; women

\section{Introduction}

Indonesian media coverage in March 2017 was colored by news about several cases of child abduction. Information about the abductions, along with murders and other crimes, spread through online messaging communities. Abductees were reported to have body parts removed and sold at high price on the black market. Messages about how and why these abductions occurred spread across the country, and causing widespread anxiety.

A message spread initially in Cimahi City, West Java, for example, reported that a man pretending to be mentally ill was carrying a child in a sack in Pojok, Cimahi City. The message encouraged people, especially parents who have children under 10 years old, to always be cautious and to make sure children are always supervised when outside. The message was accompanied by two photographs: one of the abductor with his hands tied up, the other of two children with their arms and legs bound. However, Cimahi Police Resort Chief, Ade Ary Syam Idradi reported that the content in the message was not true (Nazmi, 2017).

Similar messages about child abduction are also common in Jakarta because of messages broadcasted on WhatsApp. However, though the suspect in Cimahi pretended to be mentally ill, in Jakarta he was disguised as an online-based ojek driver. Through WhatsApp, the message quickly spread to the public and received media attention.

Jagakarsa Police Chief Kompol Sri Bhayangkari confirmed on an online news 
Picture 1.

One of the broadcasted messages of child abduction

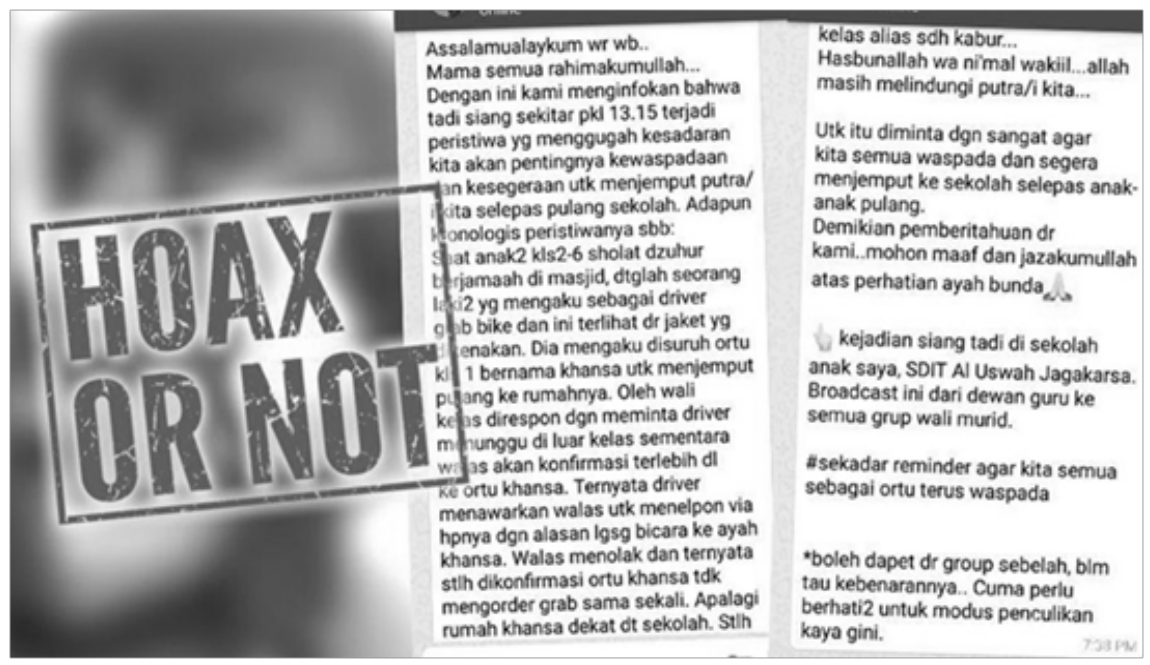

Source: Batubara (2016)

portal that he had also received a report about this case and asked his staff to conduct a search for the missing abductees. The Police Officer has come to SDIT Al Uswah Jagakarsa and met with the school's representative. According to the principal's information, the WhatsApp messages were untrue (Batubara, 2016).

On the national level, Chief of Police of the Republic of Indonesia, Tito Karnavian (2017) stated that the child abduction news circulating through short messages and in cyberspace were all hoaxes. According to Tito, the persons spreading news about abductions aimed to delegitimize government authority and stir up social unease, with the goal of altering the political momentum around the elections of regional heads. Tito asked parents to ignore the stories about abductions and to remain wary of other hoaxes (Prabowo, 2017).

There is nothing inherently wrong with messages saying that children need a proper protection and attention, especially in a city. However, when these didactic messages are conveyed using false information, such messages can be harmful. The messages about child abductions were damaging because they compromised feelings of safety and even resulted in death. In March 2017, at the height of the child abduction messages on WhatsApp, a resident from Pontianak City named Maman Budiman was beaten to death by mobs because he was suspected of abducting a child. Maman was visiting his son's house in order to visit his grandson. Unfortunately, he did not know exactly where his son's house was. Because Maman looks confused, residents suspected he as the rumored child kidnapper (Nurdin, 2017). Similar deaths also occurred in Serang, Banten. One victim was suspected as having a mental disorder (matching the narratives in the abduction messages) and died after being beaten by hundreds of people on the street (Nurdin, 2017). In these cases, the hoax messages are no longer just disturbing; they have threatened the tranquility in social life.

The impact of hoax messages is strengthened with the existence of mobile instant messaging applications, such as WhatsApp, that can easily broadcast the messages online. The phrase, "I got this from another group," is often used by WhatsApp users to spread information when the original source is not known. Instead of verifying the content of the message, users often choose to spread these messages because it's easier to do. Additionally, because users can share information in multiple 
WhatsApp chat groups, spreading these messages happens at an accelerated rate. Moreover, the fantastic number of WhatsApp users in Indonesia makes the country and ideal "market" for broadcasting hoax messages.

In August 2016, the ComScore research company reported that WhatsApp is the most popular mobile application in Indonesia and has a staggering 35.8 million users. WhatsApp not only has the most users of any app in Indonesia, but it is also one of the most frequently used applications, after Facebook and LINE. Compared to email, WhatsApp facilitates faster information exchange, and the average amount of time spent using WhatsApp is about eight hours a month. This report shows WhatsApp's superiority over other chat apps, such as Blackberry Messenger with 34.7 million users, and LINE with 27.6 million users (Pratama, 2017).

Although gender-based WhatsApp user data has not been released, research by Accenture, in cooperation with Femina magazine, reveals that most women that were participants in those research using the internet for social connection. And that's make WhatsApp a must-have application (Fajriningtyas, 2016). A study from Liliek and Samudi (2017) showed that Indonesia ranked second from the bottom of the 31 countries surveyed in their level of digital fluency. From that position, men's digital fluency tended to be higher than women's, which has been supported by other research (Liliek \& Samudi, 2009). Lilik and Samudi (2009) also supported the findings of the Accenture study since women are described as more interested in social relationships, while men are more diligent in finding latest information.

That women tend to seek out social relationships through technology while being less technologically literate creates a deadly brew that may interest researchers. Thus, the aim of this study is to investigate further the role of women in circulating hoax news in order to find preventative measures that may decrease the spread of false information. In light of this goal, the primary research question of this study is as follows: How do women, especially mothers, process hoax messages about child abduction on the WhatsApp instant messaging application?

This research begins with a comparison of several previous studies related to this research, then continues with the basics concept that used in this research, then the results of the study, which ends with discussion and conclusion.

\section{Previous Research}

Widya Wuri Nugrahaedi's research (2008) examined the factors that affect individuals' attitudes to hoax e-mail hoax using quantitative methods from a positivist paradigm. The four factors studied were fear, credibility of the source, cognitive needs, and media literacy. The results of the study mentioned that attitudes toward hoaxes are strongly influenced by the level of fear that an individual has. A positive attitude to a hoax (means that the person accept the hoax news) is likely arise if the individual has a high degree of fear, but the credibility of the source, cognitive needs, and media literacy showed no meaningful correlations.

If the study looked at the factors behind attitudes to hoaxes via email, while this study focuses more specifically on how women's attitudes towards hoax messages, especially messages about child abduction, on WhatsApp. Thus, this research aims to add a point of view about hoax news processing from a different paradigm, with a different method, on different media, and with a more specific target group.

Clara Novita Anggraini's research (2016) focused on new media literacy and the dissemination of hoax information. Her study aimed to look at student's new media literacy skills in spreading hoax information and the knowledge required and motivations behind spreading hoax information. Phenomenological 
methods were used to explore the activity of media awareness of the students when disseminating information. The results showed that the literacy skills of two students who spreading hoax information in this study is very low and the people do not have any media literacy skills.

Despite similar topics about hoaxes spread through WhatsApp, this study focuses on hoax message about abductions and processed by women, especially mothers, and uses Richard Petty and John Cacioppo's theory as a guide.

Liliek Budiastuti Wiratno and Samudi's research (2009) said that women are marketing and product targets in the media, based on they research in Semarang, Indonesia. Women thus need good knowledge about the media industry to adequately filter the information offered. The study looked at the position of women as a filter for their children in consuming media messages, while this study looks at women's position in processing messages, mainly hoax messages about child abduction.

\section{Literature Review Hoax}

The word of hoax has become a popular word to fabricated, false, or fake events, especially in cyber media texts:

A hoaxs not just a form of news or opinion, but also includes data, photos, and images. In the context of cyber media, hoaxes can be interpreted as text used as false news or deceptive efforts spread through cyber media to the reader to trust everything (Triartanto, 2015, p. 33).

More than simply deceptive, hoaxes can also bring people into conflict and are even (rarely) used for personal benefit. According to Salomon (2009) and Milhorn (2007), hoaxes are often meant to joke or other people into believing something which is actually untrue or fake. Milhorn (2007) also said that hoaxes are not always aimed at financial gain and simply provide entertainment, as with any other joke, or a feeling of superiority. Prank creators often just want to play around, but these actions sometimes have serious consequences.

Dunn et al. (2005) report that most hoaxes found on the internet can be classified as either internet chain letters, computer virus/ software hoaxes, medical hoaxes, rumors, jokes, or legends. Internet chain letters may take on many forms: some require that the receiver pass on information to others in a group (usually by way warnings or threats if information is not directly passed on to a certain number of people), while some appeal into a receiver's greed or sympathy (Dunn et al., 2005). The present study focuses on abduction hoaxes because their messaging plays the recipients' feelings to encourage further dissemination.

\section{WhatsApp}

WhatsApp is an instant messaging application for smartphones that allows users to send and receive real-time location information, images, video, audio, and text messages to individuals and groups at no cost (Church \& De Oliveira, 2013). WhatsApp requires a mobile internet connection to work, and two parties must have WhatsApp software installed on their phone to communicate through WhatsApp. WhatsApp provides additional social information to its users as users can see when friends are online, when they are typing a message, and when they last accessed the app (if that feature is enabled). WhatsApp also provides delivery notifications for when messages are sent and received by others (Church \& de Oliveira, 2013). WhatsApp is beginning to challenge large social media platforms like Facebook and Twitter, traditional texting, and even email (Saner, 2016).

Church and de Oliviera (2013) found that there are eight factors that motivate users to choose WhatsApp over other messaging services. The first is WhatsApp's low cost because it is internet-based. Second is social 
influence, which means users choose WhatsApp because close relatives and friends also use the app. A third factor is that WhatsApp has no character limit for messages, unlike some other platforms. Fourth, WhatsApp facilitates group chats and a sense of connectedness. WhatsApp considered a more personal app and is commonly used in communities with close relationships. Fifth, becasuse its immediacy, privacy concern \& expectation. WhatsApp users assume that messages sent via this app would always be read and receive an immediate reply. Furthermore, additional features allow its users to see the online status of other contacts, and the status of sent messages (a single check means sent, a double check means delivered, and a blue check means read). WhatsApp also allows its users to block messages sent from other users. Sixth, WhatsApp is reliable. For its users, WhatsApp messages are assumed to always be delivered to the receiver. Seventh, WhatsApp provides another technological means to communicate. The eighth factor is WhatsApp's notification handling mechanism, which allows users to turn off notifications from a group or mute notification entirely.

WhatsApp was chosen as the instant messaging application used in this study because, referring to Fajriningtyas' (2016) research about working women in Indonesia, WhatsApp is seen as a mandatory application for smart phones. This study thus focuses on how mothers process hoax news about abductions through chain messages on WhatsApp.

\section{Elaboration Likelihood Theory}

The Elaboration Likelihood Model (ELM) provides a general framework for organizing, categorizing, and understanding the basic processes underlying the effectiveness of persuasive communications (Petty \& Cacioppo, 1986). The ELM began with attempts to account for the differential persistence of communication-induced attitude change.
Reviewing the literature on attitude persistence revealed that the many different empirical findings and theories in the ELM field might profitably be viewed as emphasizing one of just two relatively distinct routes to persuasion (Petty, 1977; Petty \& Cacioppo, 1978, on Petty \& Cacioppo, 1986).

The first type of persuasion results from a person's careful and thoughtful consideration of the merits of the information presented in support of an advocacy (central route). The other type of persuasion, however, points to factors in the persuasion context (e.g. an attractive source) that induced change without necessitating scrutiny of the merits of the information presented (peripheral route). In the accumulated literature, the first kind of persuasion appeared to be more enduring than the latter (Petty \& Cacioppo, 1986). This theory exposes the differences in evaluating critical arguments depending on how a person processes information. There are two ways, namely central and peripherals. Elaboration and critical thinking refers to the central, nonelaborating, and minimal critical thinking route that refer to the peripheral path (Littlejohn, 2010).

When using the central route, people consider an argument carefully, and if their attitudes change, then the change tends to be fixed and will affect how they behave. Conversely, if a peripheral route is used, the changes are usually temporary, and do not have much effect on behavior. The critical way of thinking is influenced by two main factors, namely motivation and ability. When our motivation is high, people tend towards the central route, and when motivation is low, people tend to follow our peripheral route. Motivation is influenced by at least three factors. The first is the involvement, or how far a topic is relevant to someone The second factor of motivation is the diversity of arguments. The more diverse the arguments from various sources, the more someone will be able to think before making a decision. The third factor in motivation is the tendency of 
people to enjoy critical thinking. However, no matter how motivated people are, they still cannot use central processing if they lack the ability to do so.

The chart below illustrates central and peripherals processes. Referring to the illustration below, if someone is not motivated and does not have the ability to process messages, they are not using a peripheral route. If someone is motivated and able to process messages, then the message will be processed with reference to the knowledge that person has. However, when the perceived knowledge is not enough, that individual will return to the peripheral path.

\section{Media Literacy}

According to Potter (2014), media literacy is a set of perspectives through which an audience opens itself to media and interprets

Picture 2.

\section{Elaboration Likelihood Model}

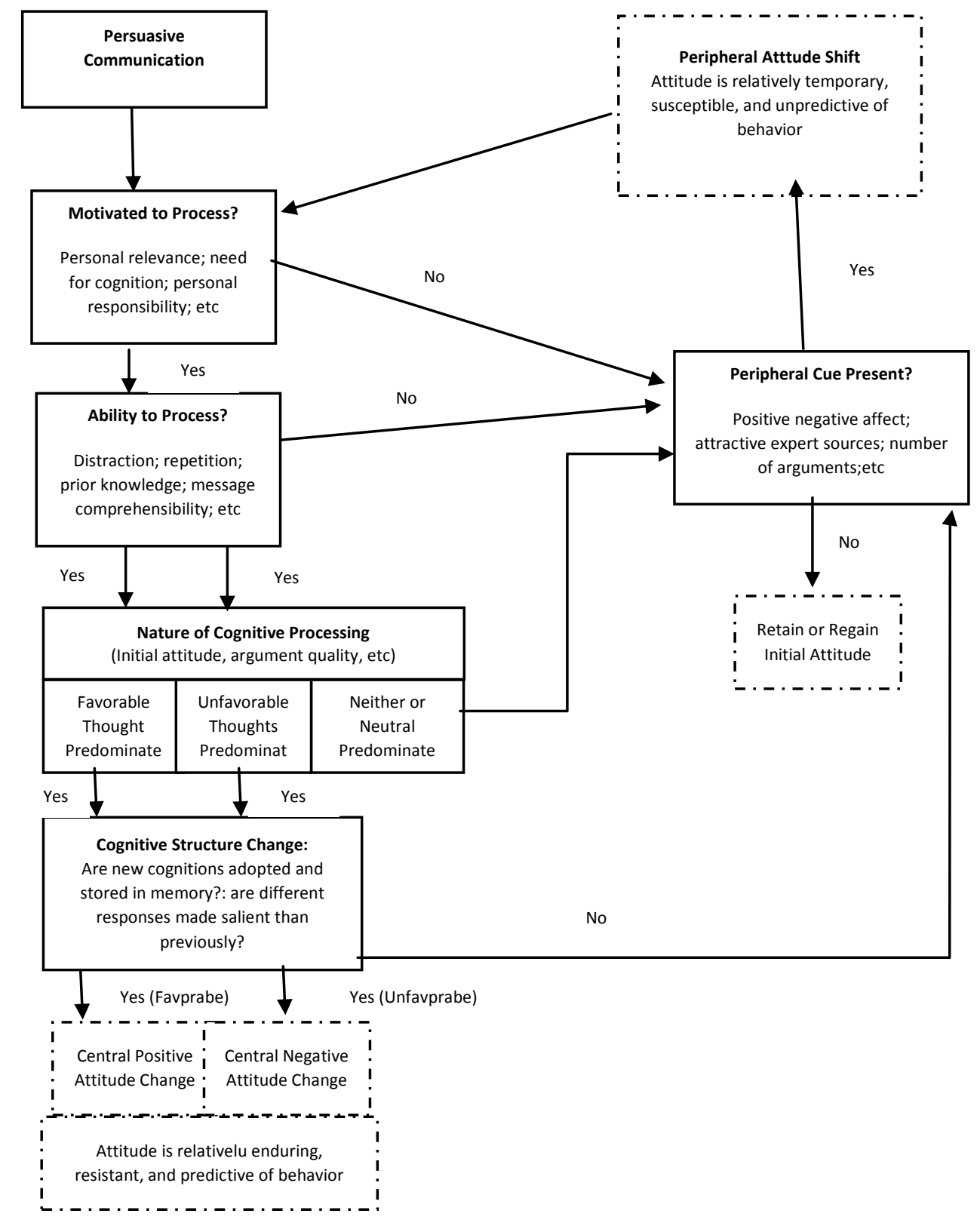

Source: Petty and Cacioppo (1986) 
the meaning of the messages it carries. Potter explains that there are three building blocks of media literacy: personal locus, knowledge structures, and skills. Personal locus refers to people's purpose and energy. Purpose leads people to the information they really need and ignores another information that is not needed. Meanwhile, energy will encourage individuals to gain that information. The more individuals recognize their personal locus, the control comes with information processing. Knowledge structures refer to a set of organized information in human memory. This structure helps individuals see patterns that map out pathways to gain information. The more knowledge structures an audience has, the more media can be consumed. Skills refers to the tools used by individuals to construct their knowledge structures.

To have good media literacy skills, one must have the ability to access media, analyze media content according to context, criticize the mass media, and write their own messages in various forms and types of media. Trisilowaty (2012) in her journal's article entitled Freedom of Information in the Age of Online Media stated, when situations where information comes in abundance from many sources, we need to increase maturity and awareness in sorting the incoming information. Which one is the good one, which one is true or doubtful one. Because with the good ability of media literacy, an individual can understand and being critical with what is conveyed by the media, so it is expected to counteract the negative effects caused by media.

\section{Methods}

This study uses a qualitative approach to understand women's attitudes toward hoax messages about child abduction on WhatsApp. This research was conducted via interviews and a survey to understand the experience and opinions of each research subject to gain qualitative data.
The interviews in this study were between researchers and informants selected to provide information about her reactions to WhatsApp hoax messages about child abduction. Each informant was chosen by using purposive sampling technique, which gives specific criteria based on the character of the target population. The criteria is: a) woman; b) mother; c) WhatsApp user for at least 1 year; $d$ ) uses WhatsApp more often than any other mobile instant messaging app; and e) incorporated in chat groups in WhatsApp. This criteria were chosen based on the needs of researchers and to ensure that informant has sufficient experience to be asked about the theme of this research.

Purposive sampling in this study generally used a heterogeneous sampling method to collect data from people with different views that may not be proportional to the real population. The final sample group included two mothers with different occupational backgrounds, one a housewife and the other a working mother, to see the tendency of opinions in each job category. Separation of this category refers to previous research (Ananda, 2013) which saw differences in the psychological characteristics of women in those categories. The names of informants used in this study stated below:

Table 1. List of informants

\begin{tabular}{cccc}
\hline No & Name & Profession & Addresse \\
\hline 1 & W & Stay at Home Mom & Depok \\
2 & DNA & Working Mom & Cimahi \\
\hline
\end{tabular}

Source: Author design

The questionnaires through a Google Form link in this study were distributing openly by researchers via WhatsApp, some of which forwarded message back to her WhatsApp friends. At the end, researchers found 56 participants who match with the criteria for this study. 


\section{Results}

\section{Quantitative Data}

Based on the results of this study, it can be seen that $66.1 \%$ of the women claimed to have received messages about child abduction along with organ theft through WhatsApp, while $17.9 \%$ never received these messages, and the remaining $16 \%$ forgot whether they had received the message.

Of the $66.1 \%$ who received the messages, $83.3 \%$ of them stated they came from a friend, $5.6 \%$ received them from family, $5.6 \%$ received them from an unknown person in a group, and $5.6 \%$ others forgot the source of the messages. Most respondents, $60.7 \%$, believed that the messages were made by the people who knew about the incident directly, while $12.5 \%$ thought the messages were made by the victim's family. Another 7.1\% assumed an authorized officer made the messages, while the other $19.7 \%$ thought they were created by irresponsible people not related to events.

Furthermore, when respondents were asked if they would share information about child abduction cases, $57.1 \%$ of respondents said they would share the news and $42.9 \%$ say no. Of those who said they would share such news, $78.6 \%$ claimed the primary reason was to increase awareness, $1.8 \%$ said it was because proximity to the incident geographically or personally, and the rest said they wanted to help the families of the victims. Those who would not to share the information said the primary reasons were that the message they received was not clear and that they did not want to add to existing social anxiety. However, $80.4 \%$ of respondents stated that the information about child abduction has benefits. Only $5.4 \%$ of all respondents stated that the information was not useful, while the rest assumed that the message may or may not be useful.

The questionnaire also asked about what the women do when they receive a broadcast message on WhatsApp. When asked whether they would search for the truth of the broadcast messages they receive, $46.4 \%$ of them declared that they do so. Another $33.9 \%$ said they do not like doing that, while the other $19.7 \%$ said they only sometimes do.

Next, in relation to discussion activities conducted by women after receiving broadcast messages through WhatsApp, $44.6 \%$ of them stated that they like to discuss it. The other $28.6 \%$ said they do not like to discuss the messages they receive. The other $26.8 \%$ say they sometimes do that. Other questions related to the trustworthiness of a message source: $64.3 \%$ of the respondents declared that they do not immediately accept the truth of a message, even when it comes from people they trust, while the other $23.2 \%$ stated that they would be able to immediately believe such messages. The rest thought they may or may not immediately believe a message from a trusted source.

Respondents were also asked about whether they had trusted people to share the news with them about child abductions. Trusted here means that when he/she tells the news, can immediately believe it. Fifty-one-point-eight percent of respondents stated they had those kind of people. Meanwhile $8.9 \%$ stated they did not had that, and $39.3 \%$ responded they doubt whether they had or had not.

How then do women distinguish whether a message they receive via WhatsApp is real or deceptive? Starting from the most common method, the four ways that respondents used to check the truth of a message included: 1 ) checking if there is similar information in mainstream media; 2) viewing the contents of the message; 3 ) seeing who sent the message; 4 ) seeing how many the same message that received by respondents.

\section{Qualitative Data}

The issue of child abduction was an important issue for our respondents. When asked what they thought when they heard the phrase "child abduction," common responses included fear, anxiety, pity, and anger towards the perpetrator. From a sense of responsibility 
as mothers, both female informants interviewed by researchers claimed to have given special attention to the child abduction cases that became viral in 2017. They both also continued to stay alert for information about dangers to their children, wherever they may be. For home, for example, there is a group chat called "Arisan Ibu-Ibu" on WhatsApp, which shares the latest information related to the dangers for children. For school, there is a group chat of fellow students' parents, and one of the conversation topics is about child safety and security in the school environment.

The feeling of fear associated with these abduction messages also made both respondents feel that the message was important to be spread. By sharing these messages, they would make others aware of various motives that are usually done by the perpetrators of abduction. They both agreed that messages about abductions make them more alert and cautious with their children in different environments. Messages about children, especially those related to child safety, lead me to read those messages more carefully (W, 2017). They believe that the messages about abduction come from the community near the incidents, making it easy for them to immediately trust the messages they received. This was especially true if the sender was a person they trusted or was sent repeatedly from different sources.

The main difference between informant DNA and informant $W$ is evident in the way they followed-up after receiving the message. Their alertness manifested in different ways. DNA preferred to refrain from spreading the message with the assumption that the same message is usually already spread from different chat groups, while $\mathrm{W}$ preferred to immediately spread the information the moment she received it. W's reasoning corresponded with the qualitative data: she did not want the same incident to occur in her territory, so she wanted everyone to be aware of the danger.
Furthermore, $\mathrm{W}$ even felt anxious to see any vehicles or people whose movements were suspicious around the school environment. She admitted that she often looked for suspicious activity, such as a mysterious car or a stranger making odd gestures, around the school if she was nearby.

This study also found that there are differences in how child abduction messages were received by $W$ and her partner. $W$ received messages about child abduction with feelings of worry, fear, and anxiety. However, when she tried to communicate these messages to her spouse, her spouse told $\mathrm{W}$ to make a filter when she received the message. According to $W$, in her partner's point of view, she is a woman who can be easily made to believe anything. The first thing her partner asked when she shared the information was about where she got the information, the validity of the news, and whether the sender actually knew about the event. During the interview, W said: "In fact, Ijust know from my husband that eventually there are people who take advantage financially from spreading false news in the media, something that never crossed my mind before."

W said she usually found out the truth of the messages after discussing them with her husband. Her husband who told her which messages were true and good to spread to others, as well as ones that are false and should only be for personal consumption. Before talking with her husband, W said she often talked about the message with her friends on her group chat, ignoring the truth of the message. In W's mind as a housewife, the responsibility of her children safety is in her hands, unlike when she had a career and felt that responsibility was shared with her mother, who helped her to look after the children during work hours.

DNA said she tended to consider the relevance of such messages from a few points: 
“Don't believe right away. I evaluate the message in terms of logic, message structure, and the main source of information that I trust, namely newspapers or magazines."

Although she confessed, she also discussed the messages with her husband several times, DNA did not treat her husband as her main information filter. She also claimed to prefer to send wisdom quotes, and information about business and parenting. Although the message about children is priority for her, DNA did not hastily send the abduction information to her circle of friends. She preferred to keep the message for herself, especially for her self-awareness as a woman working outside the home.

\section{Discussion}

\section{Women and Information Evaluation}

Based on the ELM, there are two paths that one uses when they receive a message, the central path and the peripheral path. Central routes focus on the need for critical argumentation, while peripheral routes are more superficial and tend to change behavior only temporarily. As mentioned earlier, critical thinking is influenced by two things: motivation and ability. Motivation itself is influenced by at least three things, namely the involvement, diversity of arguments, and people's tendency to enjoy critical thinking.

Based on the results of the research above, it is interesting that women actually a have high motivation to think further about WhatsApp hoax messages about child abduction. Their involvement in the issue of child abduction arises from their sense of responsibility to children.

Once respondents received a message about child abduction, there was a push to find out the chronogical and motive behind the incident. The information they often get from different WhatsApp groups chat complements each other. As informed by informant $\mathrm{W}$, she always trusted every message she received because there was often similar information from other groups, complete with pictures or video that confirmed the message. The community and sense of connectedness on WhatsApp stand out in this aspect.

Because women engage directly with these messages, they play a significant role in ensuring (or not) if a message spreads in WhatsApp. However, this study showed a lack of critical engagement with those messages. As the informants mentioned, there is an affirmation of previous information or an emotional response that obscures the truth of the message itself. This is also seen in the quantitative data which showed that the first response of women is to spread the information, even when the original source of the message is unclear. Moreover the hoax message about child abduction is assumed as if no one would be harmed because it is about humanity. So, for the sake of awareness, the message that may actually be a lie seems to be forgiven.

The third factor is the tendency of to enjoy thinking critically. Based on this study's results, $40 \%$ women love to talk and discuss the messages they receive. They, who also enjoy to discussing and finding out the truth about the message, are quite high, in the $40 \%$ range. However, through the findings during the interviews, it was confirmed that their enjoyment of thinking critically was often dominated by emotional responses to abduction messages. As a result, many women assume information about these child abduction cases should be spread immediately for the sake of social awareness. Because for the female respondents, people out there will believe in the message, even though they themselves don't believe it.

The pleasure of critical thinking among female respondents appears in the tendency to check messages from channels other than WhatsApp, such as social media and online news portals. Even so, it cannot be denied that 
the channels cannot guarantee that the info provided is valid and reliable. Unfortunately, some of these other sources are equally biased, meaning people who originally wanted to find out the truth of a message can become trapped in circulating hoax messages. Therefore, information about how to improve critical thinking and women's ability distinguish between true and false information is a necessity. Such knowledge involves developing skills in media literacy.

Based on the analysis above, the tendency of women in Indonesia receiving WhatsApp messages about child abduction is to process those messages through a peripheral route. Persuasive messages about child abduction are often accepted by women who feel motivated because of a personal responsibility they have. Though they have the skills and opportunity to access mass media, worries and anxiety shape message processing rather than more critical approaches. Because these initial emotional responses dominate message processing, there is no deep change in cognitive structure. The assumption is that information about abduction is dangerous and that it is better to alert others than ignore the information.

Robert Cialdini mentioned six cues that trigger a response program "click whirr". This gesture allows one to fly to the peripheral route with automatic steering: 1) Exchange (reciprocation); 2) Consistency; 3) Social Proof; 4) Desire; 5) Powers; 6) Scarcity (Griffin, 2012). The female respondents in this study at least show consistency sign and social proof that: "The message of child abduction is a useful message, and we all need messages that make us aware, right?" This process through peripheral routes also explains how for some people, the message can manifest an unpredictable attitude. Examples of such behavior include the persecution of innocent people who are falsely accused as abductors (as discussed before) or the excessive worry that

Picture 2.

\section{Peripheral Routes}

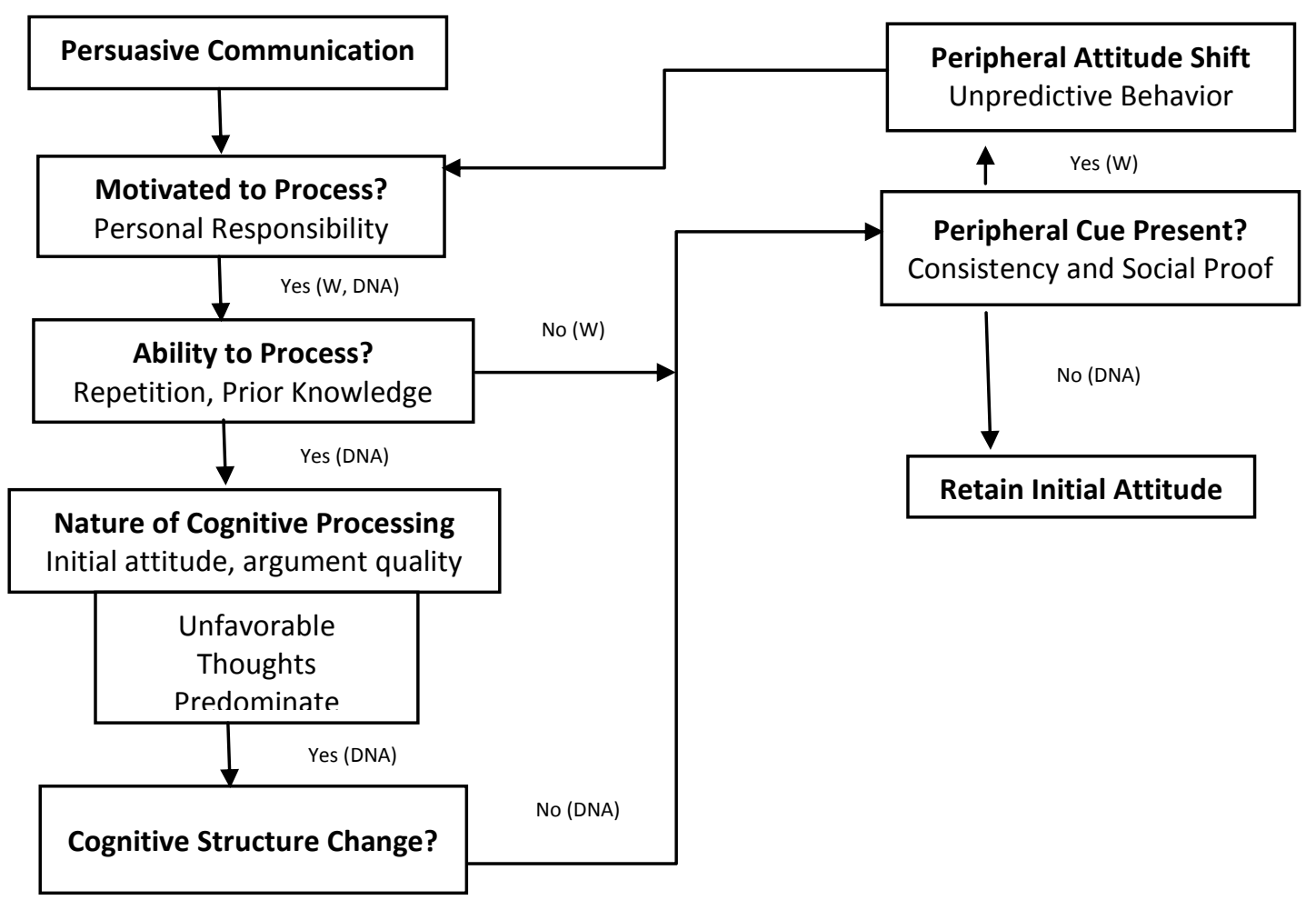

Source: Author design based on Elaboration Likelihood Model 
caused W sometimes stop by her child's school. Though both $\mathrm{W}$ and DNA both processed on peripheral pathways, DNA tended to refuse to accept the truth of messages automatically. Until she tended to retain what was already in her knowledge, without causing any change of certain character temporarily. In the end, both DNA and $W$ both pass peripheral routes, even though in the course of the DNA route is more complicated than W.

\section{Women and Media Literacy}

There are several capabilities needed to be media-literate: an ability to access media; an ability to analyze media content according to context; an ability to evaluate and criticize media messages; and an ability to write their own thoughts in various forms and types of media (Livingstone, 2003).

In terms of media accessibility, according to the results of this study there is no difficulty for women to access the media in Indonesia. They revealed that they could easily reach the various media they wanted information from, either social media, online media, or mainstream media such as TV, radio, newspapers, and magazines. In terms of their ability to write their own messages in various forms and types of media, all participants declared that they had mastered all of WhatsApp's features. Such knowledge includes knowing how to write with different font variants (bold, italic-for example), use emoticons, send pictures and videos, make voice and video calls change download settings automatically.

There are two other capabilities that should be improved, however: the ability to analyze the contents of messages in context and the ability to criticize messages. These abilities are often overlooked when encountering a humanist message that touches one's emotional side, such as stories about child abduction. This study shows that these capabilities could still be improved upon.

\section{Conclusions}

From this investigation, we can conclude that women as a mothers, especially they who being respondents to this research, tend to process hoax messages about child abduction through peripheral lines. Although women have a high motivation to process messages because they feel involved with the issue, but motivation to explore a diversity of arguments and take pleasure of critical thinking are often ignored. In terms of ability, women are capable of thinking critically, but messages about child abduction tend to be biased by emotional responses rather than an analysis or criticism of message content. So, when they receive the hoax message about child abduction, they will be more easily tempted to send it again to the others. They assumed as if no one would be harmed because it is about humanity. So, for the sake of awareness, the message that may actually be a lie seems to be forgiven.Second, improving women's media literacy could help stop the circulation of hoaxes on WhatsApp about child abduction. Third, changes in attitudes caused by hoax messages about child abduction follow peripheral processing lines and are temporal and unpredictable. The researchers categorize this unpredictability as reactive behavior. Based on this research, this can cause various disadvantages, such as excessive fear and uncontrolled anxiety.

One recommendation based on this study is to promote community-based media literacy course specifically aimed at women. This thinking began with the rise of online lecture communities through WhatsApp followed by groups of women. One of them is the Professional Mother Institute class initiated by Septi Peni Wulandari. The various skills a Indonesian women must possess, especially mothers, are taught in communities through online lectures and occasional offline meetings. The lecturers also alternate according to the skills being taught. With the number 
of WhatsApp users in Indonesia, WhatsApp could be an ideal medium to improve media literacy. Finally, however, this research has weaknesses, especially from the sample size, so the next researcher can increase the sample size to get a richer and more diverse story. This research also only sees women as mothers, while beyond that there are still many sides of a woman, or even other groups outside the category based on gender, that can be studied. This research leaving further opportunities for future research to explore hoax processing on WhatsApp.

\section{References}

Ananda, M. R. (2013). Self-esteem Ibu Rumah Tangga yang Bekerja dengan yang Tidak Bekerja. Jurnal Online Psikologi, 1(1).

Anggraini, C. N. (2016). Literasi media baru dan penyebaran informasi hoaks. Yogyakarta: Universitas Gadjah Mada.

Batubara, H. (2016, October 27). Pesan berantai penculikan anak modus menyamar jadi ojek online. Retrieved November 7, 2017, from https://news.detik.com/ berita/d-3330564/pesan-berantaipenculikan-anak-modus-menyamarjadi-driver-ojek-online

Church, K. \& de Oliveira. (2013, August 30). What's up with WhatsApp? comparing mobile instant messaging behaviors with traditional SMS. Retrieved from http://www.ic.unicamp.br/ oliveira/doc/ MHCI2013_Whats-up-with-WhatsApp. pdf

Dunn, H. B. \& Allen, C. A. (2005). Rumors, Urban Legends, and Internet Hoaxes. In Johnston, T. C. (Eds.), Proceedings of The Annual Meetings of The Association of Collegiate Marketing Educators (pp. 8591). Martin, TN, US: The University of Tennessee at Martin.

Fajriningtyas, C. (2016, May 6). Mengapa digital fluency Indonesia rendah?. Retrieved from https://www.accenture.
com/t20160506T060137__w__/id-en/_ acnmedia/Accenture/Conversion-Assets/ DotCom/Documents/About-Accenture/ PDF/3/Accenture-Femina-Vol-18Indonesia-Digital-Fluency.pdf

Griffin, E. A. (2012). A first look at communication theory ( $8^{\text {th }}$ Edition). New York: McGraw Hill.

Hennink, M., Hutter, I., \& Bailey, A. (2011). Qualitative Research Methods. Sage Publications

Littlejohn, S. (2002). Theories of human communication (Seventh Edition). USA: Thomson Learning.

Livingjohn, S. (2003). The Changing Nature and Uses of Media Literacy. London: London School of Economics and Political Science Milhorn, H. T. (2007). Cybercrime: how to avoid becoming a victim. Florida: Universal Publishers.

Nazmi, A. (2017, March 17). Beredar pesan penculikan anak di cimahi, kapolres cimahi sebut berita hoax. Retrieved from http://jabar.tribunnews.com/2017/03/17/ beredar-pesan-berantai-penculikananak-di-cimahi-kapolres-cimahi-sebutberita-hoaks

Nugrahaedi, W. W. (2008). Faktor-faktor yang mempengaruhi sikap individu terhadap email hoax. Jakarta: University of Indonesia.

Nurdin, A. (2017, March 29). Hoax penculikan anak berujung korban. Retrieved November, 7 2017, from http://news. liputan6.com/read/2902507/hoaxpenculikan-anak-berujung-korban.

Petty R. E, \& Cacioppo, J. T. (1986). The Elaboration Likelihood Model of Persuasion. USA: Academic Press Inc.

Potter, W. J. (2012). Media literacy 6th Edition. London: Sage.

Prabowo, D. (2017, November 7). Kapolri: isu penculikan anak hoax. Kompas.com. Retrieved from http://nasional.kompas. com/read/2017/03/23/11093071/kapolri. isu.penculikan.anak.hoax 
Pratama, A. H. (2017). Laporan ComScore: WhatsApp adalah aplikasi terpopuler di Indonesia. Retrieved from https:// id.techinasia.com/comscore-WhatsAppadalah-aplikasi-terpopuler-di-indonesia

Salomon, D. (2006). Foundations of Computer Security. USA: Springer

Saner, E. (2016. July 3). From political coups to family feuds: how WhatsApp became our favorite way to chat. Retrieved November 7, 2017, from https://www. theguardian.com/technology/2016/jul/03/ from-political-coups-to-family-feudshow-WhatsApp-became-our-favouriteway-to-chat.

Triartanto. A. Y. (2015). Kredibilitas Teks Hoax di Media Siber. Jurnal Komunikasi, 6(2), 33-36. doi: 10.31294/jkom.v6i2.2464.g1700 Trisilowaty, D. (2012). Kebebasan informasi di era media online. Observasi Jurnal, 10(2), 127-134.

Wiratno, L. B., \& Samudi. (2009). Perempuan dan literasi media. Jurnal Studi Gender dan Anak, 4(2), 181-197. 